\title{
Devosia nitraria sp. nov., a novel species isolated from the roots of Nitraria sibirica in China
}

\author{
Lin Xu $\cdot$ Yong Zhang $\cdot$ Nicholas Read $\cdot$ Shuangjiang Liu $\cdot$ Ville-Petri Friman
}

Received: 6 February 2017 / Accepted: 13 June 2017/Published online: 24 June 2017

(C) The Author(s) 2017. This article is an open access publication

\begin{abstract}
An aerobic, Gram-stain negative, short rodshaped and motile strain, $36-5-1^{\mathrm{T}}$, was isolated from the roots of Nitraria sibirica in Zhangye city, Gansu province, north-west of China. Phylogenetic analysis based on the 16S rRNA gene sequence and two housekeeping genes $(g \ln A$ and $a t p D)$ indicated that the strain represents a novel species closely related to the Devosia, Rhizobium and Devosia genera with 98.3, 96.2 and $91.1 \%$ similarities, respectively. The strain $36-5-1^{\mathrm{T}}$ contained Q-10 as the predominant ubiquinone and 16:0 $(36.8 \%)$ as the major fatty acid; a large amount of
\end{abstract}

Electronic supplementary material The online version of this article (doi:10.1007/s10482-017-0901-z) contains supplementary material, which is available to authorized users.

L. Xu

Key Laboratory of Hexi Corridor Resources Utilization, Hexi University, Zhangye 734000, Gansu, China

L. Xu $\cdot$ Y. Zhang

Institute of Agricultural and Biological Technology, Hexi University, Zhangye 734000, Gansu, China

N. Read · V.-P. Friman $(\bowtie)$

Department of Biology, University of York,

York YO10 5DD, UK

e-mail: ville.friman@york.ac.uk

S. Liu

State Key Laboratory of Microbial Resources, Institute of Microbiology, Chinese Academy of Sciences, Beijing 100101, People's Republic of China e-mail: liusj@sun.im.ac.cn unidentified glycolipid, diphosphatidylglycerol, phosphatidylglycerol and a small amount of unidentified polar lipids were present as polar lipids. In addition, the $\mathrm{G}+\mathrm{C}$ content of the genomic DNA was $61.7 \mathrm{~mol} \%$ and the DNA-DNA hybridization with type strains Devosia geojensis BD-c194 ${ }^{\mathrm{T}}$ and Devosia pacifica $\mathrm{NH} 131^{\mathrm{T}}$ $44.1 \pm 1.1$ and $40.2 \pm 1.7$, respectively. Based on chemotaxonomic data and molecular properties, strain $36-5-1^{\mathrm{T}}$ represents a novel species within the genus Devosia, for which the name Devosia nitraria sp. nov. is proposed. The type strain is $36-5-1^{\mathrm{T}}$ (=CGMCC1. $15704^{\mathrm{T}}=\mathrm{NBRC} 112416^{\mathrm{T}}$.

Keywords Devosia $\cdot$ Novel species $\cdot$ Nitraria sibirica

\section{Introduction}

The genus Devosia was first described by Nakagawa et al. (1996) with the reclassification of 'Pseudomonas riboflavina' (Foster 1944) as Devosia riboflavina. Members of this genus are characterized as Gramstain negative, aerobic, oval or rod-shaped and nonspore forming bacteria. The genus is currently comprised of twenty one validly named species (http:// www.bacterio.net/devosia.html).

Nitraria is a genus belonging to the family Zygophyllaceae. The genus consists of 15 species of deciduous shrubs. These shrubs are widely distributed 
in the Middle East, central Asia and in north-west region of China and they have special physiological properties in terms of drought and salt resistance. These properties have been shown to prevent soil desertification, by alleviating both the soil salinity and alkalinity (Zhao and Fan 2002), and consequently, the plants have significant ecological value. Five of the species are indigenous to northwestern China. Of the five, Nitraria sibirica Pall. is the most common. The fruits of $N$. sibirica Pall. are used in some traditional medicines and are particularly recommended for the treatment of hypertension (Liu 1999). Several studies on Nitraria metabolites have shown obvious antihypertensive properties due to the regulation of digestion and spleen functioning (Tulyaganov and Allaberdiev 2001, 2003; Hadj Salem et al. 2011; Suo and Wang 2010). As yet, relatively little is known about the bacterial endophytes of Nitraria. Here we describe a novel bacterial endophyte of Nitraria, designated as $36-5-1^{\mathrm{T}}$. A polyphasic approach was carried out to classify the bacterium, and according to our current analysis, the strain $36-5-1^{\mathrm{T}}$ likely belongs to the genus Devosia.

\section{Materials and methods}

Strains and culture conditions

A root sample was collected from $N$. sibirica grown in the sand soil of Hexi Corridor to isolate bacterial

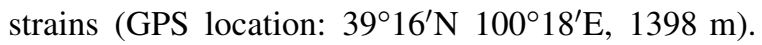
Endophytes were routinely cultured on either YMA (Vincent 1970) or LB (Bertani 1951) medium at $28^{\circ} \mathrm{C}$ and deposited as described by Xu et al. (2016). After primary analysis and sequencing of 16S rRNA, R2A agar (Reasoner and Geldreich 1985) was used to culture the strain.

Determination of $16 \mathrm{~S}$ rRNA, recA and atpD gene sequences

The extraction of genomic DNA and PCR amplification of the $16 \mathrm{~S}$ rRNA gene were conducted as described by Terefework et al. (2001). Amplification of the 16S rRNA gene was performed with two universal primers, F'-27(5'-AGAGTTTGATCCTG GCTCAGAACGAACGCT-3') and R'-1492 (5'-TAC GGCTACCTTGTTACGACTTCACCCC-3'). Ampli- fication of $g \ln A$ and $a t p D$ genes were performed as described by Gaunt et al. (2001) and Turner and Young (2000), respectively. The gene sequences were compared with a BLAST search of the nucleotide database of the National Center for Biotechnology Information (Altschul et al. 1990) and EzTaxon server 2.1 (http://www.ezbiocloud.net/; Yoon et al. 2016). Sequences were aligned using the CLUSTAL_W software (Thompson et al. 1994). Phylogenetic trees were then generated using neighbour-joining methods, maximum likelihood or maximum-parsimony with Kimura's two-parameter substitution model (Saitou and Nei 1987). The robustness of the topology of the phylogenetic trees was evaluated by bootstrap analyses based on 1000 resamplings (Galtier et al. 1996; Felsenstein 1985).

DNA base composition and DNA-DNA hybridization

The $\mathrm{G}+\mathrm{C}$ content of DNA was measured using the thermal denaturation method described by Marmur and Doty (1962) by using Escherichia coli K-12 as the standard. DNA-DNA relatedness (hybridization) was determined by using the spectrophotometric method reported by De Ley et al. (1970).

Amplification of symbiotic genes and in vivo symbiosis measured in cross-nodulation tests

Symbiotic genes, nodA and nifH, were amplified by using the primers nifHF (5'-TACGGNAARGGSGG NATCGGCAA- $\left.3^{\prime}\right) / n i f H I \quad\left(5^{\prime}\right.$-AGCATGTCYTCSA GYTCNTCCA- $\left.3^{\prime}\right)$ and nodAF (5'-TGCRGTGGAR DCTRYGCTGGGAAA- $\left.3^{\prime}\right) /$ nodAR ( $5^{\prime}$-GGNCCGTC RTCRAASGTCARGTA- $3^{\prime}$ ) with PCR conditions previously described by Elliott et al. (2007), Laguerre et al. (2001) and Xu et al. (2013). Formation of symbiosis was also measured in vivo in greenhouse pot experiments by using eight different plant species including the original host plant (Graham et al. 1991): Sophora alopecuroides, Medicago sativa, Phaseolus vulgaris, Pisum sativum, Vigna unguiculata, Trifolium repens, Glycine max, Galega oficinalis and $N$. sibirica. Briefly, plant seedlings were grown in pots filled with vermiculite moistened with $\mathrm{N}$-free plant nutrient solution (Vincent 1970), inoculated with strain $36-5-1^{\mathrm{T}}$ and formation of nodules determined visually. 
Morphological tests and physiological characterization

The bacterial strain was characterized on the basis of cell morphology including colony color, shape, size, and growth on certain media. To study the cell motility and shape, single colonies isolated from agar plates were prepared by using a JEM-1400, JEDL scanning electron microscope (SEM) and SU8010, Hitachi transmission electron microscope (TEM).

The ability to use common nitrogen and carbon sources, and resistance to common antibiotics, were tested as described by Gao et al. (1994). Additional enzyme activities and biochemical features were determined by using API ZYM, API 20NE kits and API $50 \mathrm{CH}$ at $25^{\circ} \mathrm{C}$ as recommended by the manufacturer (bioMérieux). The temperature range and salinity tolerance was investigated by incubating the bacterium on R2A agar at different temperatures (4, $10,20,25,28,30,37$ and $40{ }^{\circ} \mathrm{C}$ ) and in medium containing 1, 2, 3, 4, 5, 6, 7, $8 \%(\mathrm{w} / \mathrm{v})$ of $\mathrm{NaCl}$. The $\mathrm{pH}$ range for strain $36-5-1^{\mathrm{T}}$ was measured in R2A broth adjusted with $\mathrm{HCl}$ or $\mathrm{NaOH}$ to different $\mathrm{pH}$ values across the range from 4.0 to 13.0 at intervals of $1.0 \mathrm{pH}$ unit. Dye and chemical resistance were investigated by using methyl orange, methyl red, methylene blue, neutral red, congo red, malachite green, bromothymol blue and sodium deoxycholate at concentrations of 1 and $2 \%(\mathrm{w} / \mathrm{v})$ in R2A medium.

Predominant ubiquinone, fatty acid profile and polar lipids

Ubiquinone is an essential component of electron transfer systems in the plasma membrane of prokaryotes, while fatty acid profiling is widely used in the description of rhizobial species (Tighe et al. 2000). To measure these properties, strain $36-5-1^{\mathrm{T}}$ was grown on YMA medium with shaking at $170 \mathrm{rpm}$ for 2 days at $25{ }^{\circ} \mathrm{C}$. Cellular fatty acids were extracted and methylated according to the standard protocol described by Sasser (1990), analyzed by Gas Chromatography (GC) (model 6890; Agilent) and identified by using the TSBA6 database of the Microbial Identification System. Ubiquinone was analyzed by using reversedphase High Performance Liquid Chromatography (HPLC) and a Diamonsil C18 chromatographic column $(200 \mathrm{~mm} \times 4.6 \mathrm{~mm}, \quad$ i. $\quad$ d. $5 \mu \mathrm{m})$ with $300 \mathrm{ml}$ methanol and $700 \mathrm{ml}$ anhydrous ethanol as the mobile phase. Cellular polar lipids were extracted by using a chloroform-methanol system and separated by two-dimensional TLC using silica gel $60 \mathrm{~F} 254$ aluminium-backed thin-layer plates (Merck) (Kates 1986). The following ratios were used in the solvent system $65: 24: 4$ by volume of chloroform/methanol/ water and 80:12:15:4 by volume of chloroform/glacial acetic acid/methanol/water in the first and second dimensions, respectively. Separated components were visualized by treating the plates with a $50 \%(\mathrm{w} / \mathrm{v})$ sulfuric acid ethanol solution followed by heating at $120{ }^{\circ} \mathrm{C}$ for $10 \mathrm{~min}$. Zinzadze reagent was used to detect phospholipids.

Sequence deposition

The GenBank accession numbers for the 16S rRNA, $g \ln A$ and $a t p D$ gene sequences of strains $36-5-1^{\mathrm{T}}$ are KU358684, KY523102 and KX095238, respectively.

\section{Results and discussion}

Phylogenetic analysis based on 16S rRNA, recA and $a t p D$ sequence comparisons

Based on the 16S rRNA gene sequence analysis, strain $36-5-1^{\mathrm{T}}$ is phylogenetically highly related to members of the genus Devosia and shows close sequence similarity to Devosia pacifica $\mathrm{NH} 131^{\mathrm{T}}(98.3 \%)$ and Devosia geojensis BD-c194 ${ }^{\mathrm{T}}$ (98.6\%) (Figs. 1, S1). The phylogenetic trees based on 16S RNA genes indicated that the strain clustered with species of the genus Devosia. In addition, the phylogenetic tree based on $g \ln A$ and $a t p D$ gene sequences indicated that strain $36-5-1^{\mathrm{T}}$ fell into a coherent lineage with species of the genus Rhizobium and Devosia. The partial $g \ln A$ and $a t p D$ gene sequences were 96.2 and $91.1 \%$ similar to type strains of Rhizobium vitis and Devosia soli, respectively (Fig. 2). Considering the relatively low sequence similarities of these two genes as a cut-off for genera delineation, this data suggests that strain $36-5-1^{\mathrm{T}}$ belongs to a novel species of the genus Devosia.

DNA-DNA relatedness (hybridization)

The $\mathrm{G}+\mathrm{C}$ content for the representative strain $36-5-1^{\mathrm{T}}$ was $61.7 \mathrm{~mol} \%$ (Table 1). Two type strains of closely 


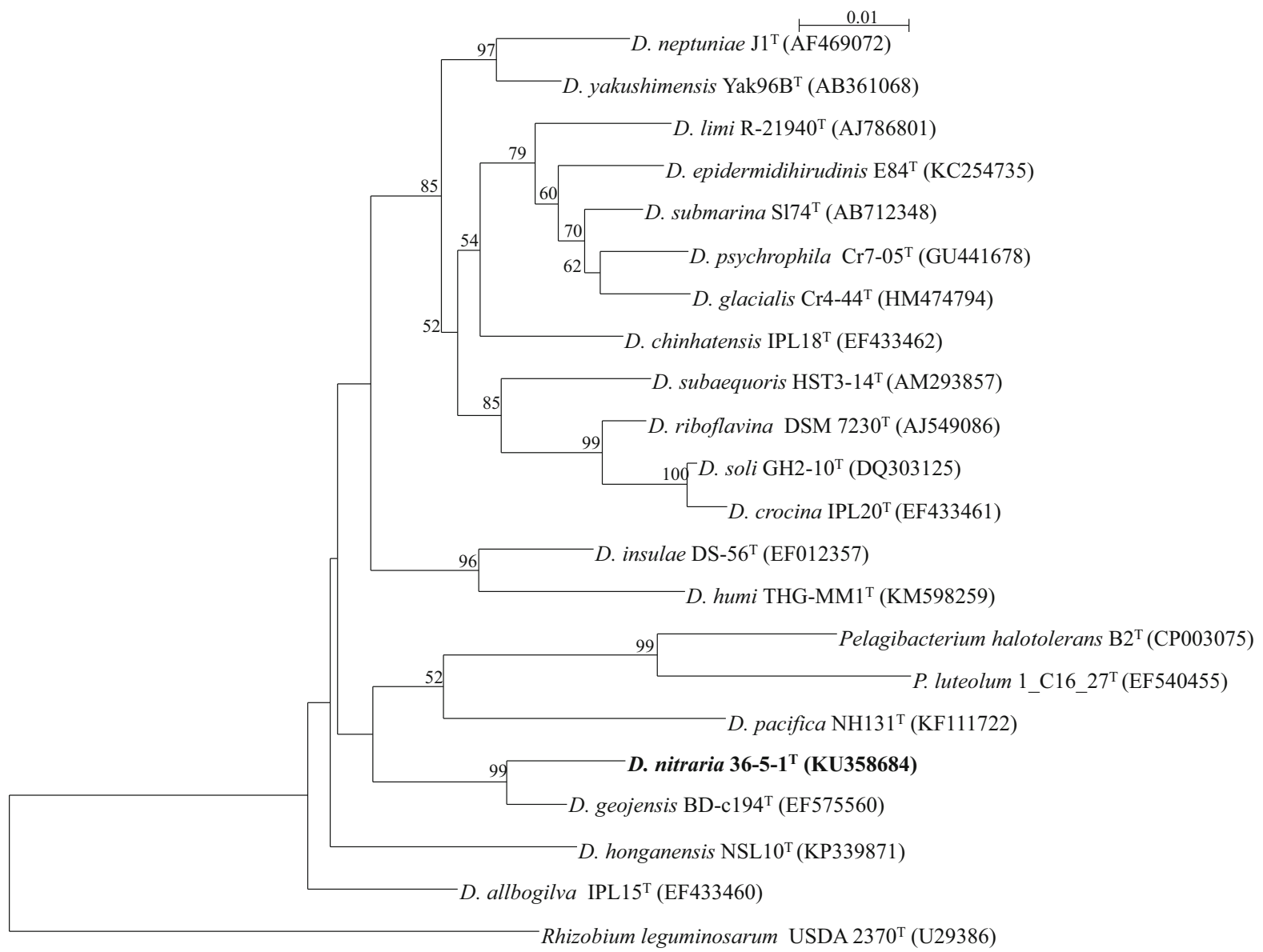

Fig. 1 Comparison of 16S rRNA gene sequences. Phylogenetic tree constructed by the $\mathrm{NJ}$ method showing the relationships between the novel species and reference strains. Bootstrap

related species, D. pacifica $\mathrm{NH} 131^{\mathrm{T}}$ and D. geojensis $\mathrm{BD}-\mathrm{c} 194^{\mathrm{T}}$, were used as the reference strains for phenotypic and the hybridization studies. The DNADNA relatedness of the strain $36-5-1^{\mathrm{T}}$ with these two closely related species was 44.1 and $40.2 \%$, respectively (Table 1).

Amplification of symbiotic gene sequences and in vivo symbiosis measured in crossnodulation tests

Some species of the genus Devosia have the ability to form a symbiosis with plants in order to fix nitrogen (Bautista et al. 2010; Rivas et al. 2003). The symbiosis encoding genes are adaptive, and in many cases, have an evolutionary history independent of the rest of the genome. We were not able to obtain PCR products for percentages above 50\% are indicated. Bar denotes for 0.1 substitutions per nucleotide position

either nifH or nodA genes by using the corresponding primers and PCR conditions described previously. Similarly, strain $36-5-1^{\mathrm{T}}$ could not form nodules on the root of any of the tested plants including its original host plant. This suggests that $36-5-1^{\mathrm{T}}$ is not able to nodulate or fix nitrogen for the tested plants.

Fig. 2 a Comparison of partial $g \ln \mathrm{A}$ sequences. Phylogenetic tree was constructed by the neighbor-joining method from Jukes-Cantor distance matrices of the sequences. Bootstrap percentages above $50 \%$ are indicated. Bar denotes for 0.1 substitutions per nucleotide position. b Comparison of partial $a t p \mathrm{D}$ sequences. The phylogenetic tree was constructed by the neighbor-joining method from Jukes-Cantor distance matrices of the sequences. Bootstrap percentages above $50 \%$ are indicated. Bar denotes for 0.1 substitutions per nucleotide position 


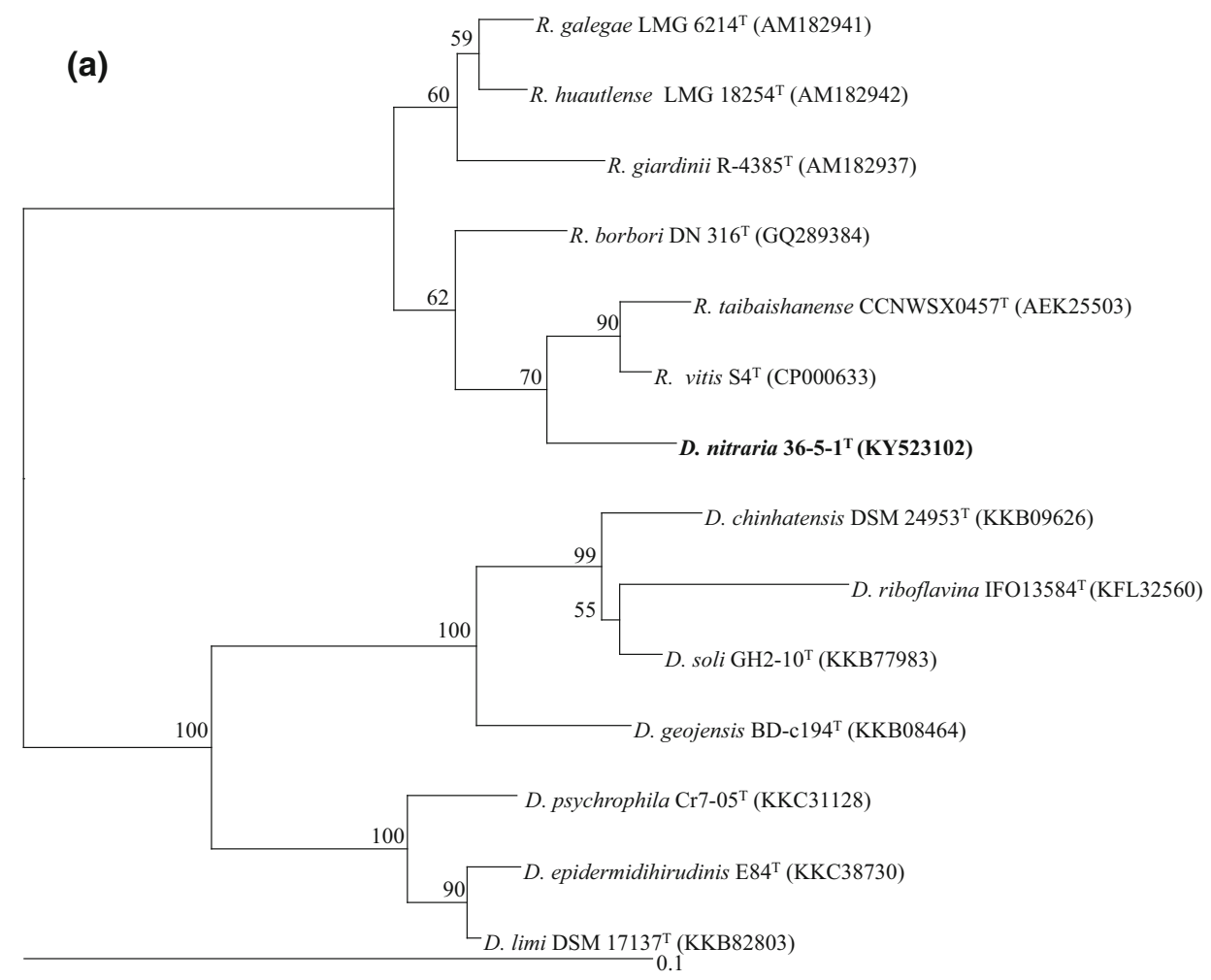

(b)

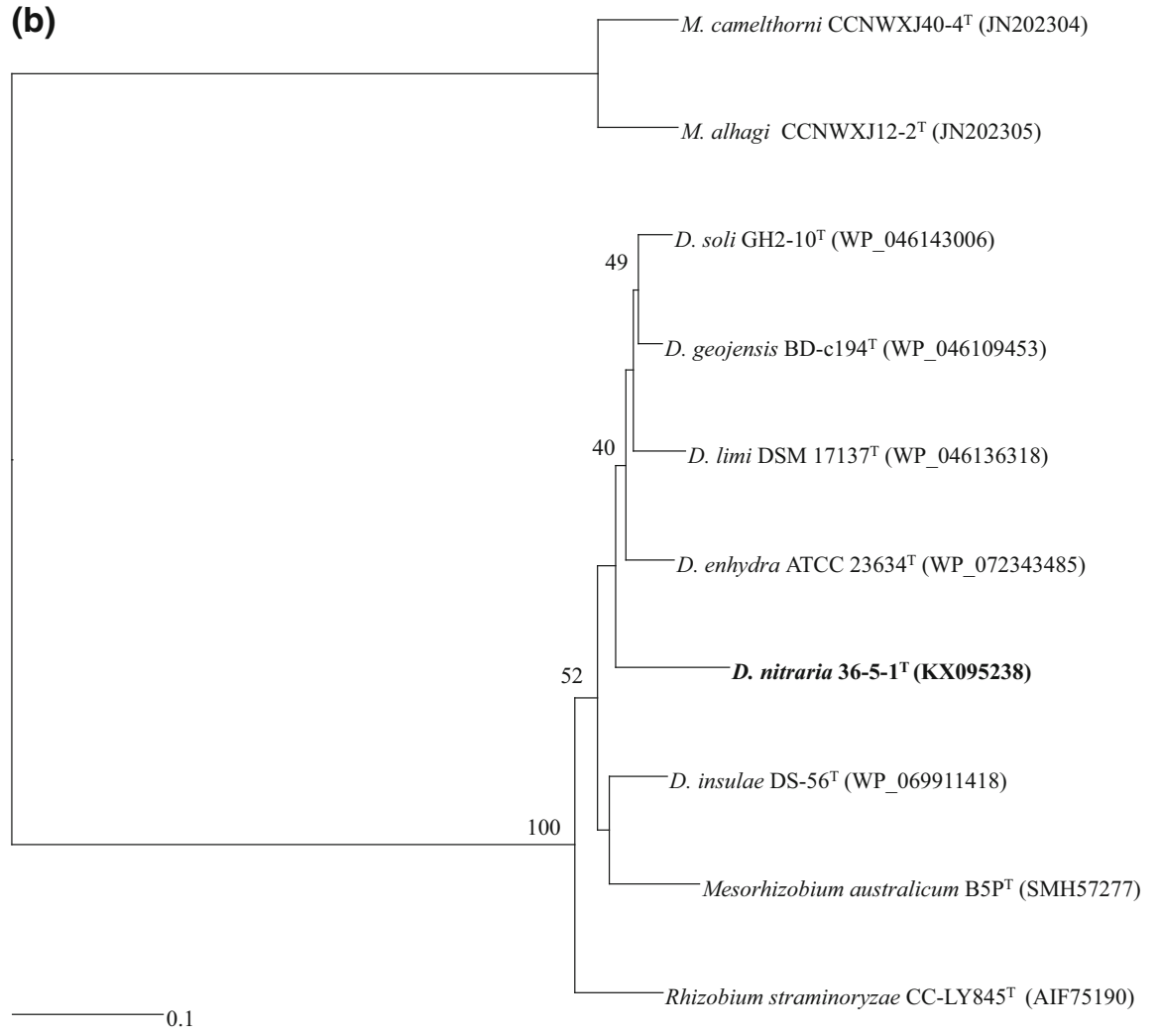


Table 1 Isolates and reference strains in the genus Devosia used in this study and DNA-DNA relatedness among them

\begin{tabular}{|c|c|c|}
\hline Strain & $\begin{array}{l}\mathrm{G}+\mathrm{C} \\
(\mathrm{mol} \%)\end{array}$ & $\begin{array}{l}\text { DNA relatedness } \\
\text { with } 36-5-1^{\mathrm{T}}(\%)\end{array}$ \\
\hline D. nitraria $36-5-1^{\mathrm{T}}$ & 61.7 & $100 \%$ \\
\hline \multicolumn{3}{|l|}{ Reference strains } \\
\hline D. geojensis $\mathrm{BD}-\mathrm{c} 194^{\mathrm{T}}$ & 60.8 & $44.1 \pm 1.1$ \\
\hline D. pacifica $\mathrm{NH} 131^{\mathrm{T}}$ & 63.0 & $40.2 \pm 1.7$ \\
\hline
\end{tabular}

However, considering there are more than 19,000 legume species, strain $36-5-1^{\mathrm{T}}$ may not necessarily have the same symbiotic test results with other legumes.

Morphological tests and physiological characterization

Distinctive phenotypic characteristics for the strains of the novel species and the type strains of the phylogenetically closest species are shown in Table 2. An electron micrograph is shown in Fig. 3.

Ubiquinone, fatty acid analysis and polar lipids

The predominant ubiquinone of strain $36-5-1^{\mathrm{T}}$ is Q-10. The major fatty acid is $\mathrm{C}_{16: 0}(36.8 \%)$ with minor amounts of $\mathrm{C}_{16: 0} \mathrm{~N}$ alcohol (14.6\%), 10-methyl $\mathrm{C}_{17: 0}(12.6 \%), \mathrm{C}_{18: 1} \omega 7 c(9.4 \%), \mathrm{C}_{18: 0}$ (7.3\%), $\mathrm{C}_{19: 0}$ cyclo $\omega 8 c(5.5 \%), 11-$ Methyl $\mathrm{C}_{18: 1} \omega 7 \mathrm{c}$ $(4.7 \%)$ and $\mathrm{C}_{18: 0} 3-\mathrm{OH}(2.5 \%)$ (Table 3). The cellular fatty acid profile was similar to the reference strains D. geojensis BD-c194 ${ }^{\mathrm{T}}$ (Ryu et al. 2008) and D. pacifica $\mathrm{NH} 131^{\mathrm{T}}$ (Jia et al. 2014) that have $\mathrm{C}_{16: 0}$ and $\mathrm{C}_{18: 1} \omega 7 c$ as their main lipids, respectively. A large amount of unidentified glycolipid, diphosphatidylglycerol, phosphatidylglycerol and a small amount of unidentified polar lipids were present as polar lipids for strain $36-5-1^{\mathrm{T}}$ (Fig. 4).

\section{Description of Devosia nitraria sp. nov.}

Devosia nitraria (Ni.tra'ri. N.L. gen. n. nitraria, referring to the host plant Nitraria sibirica).

Gram-negative, aerobic, motile (flagella), nonspore forming rod, which is $0.3-0.5 \mu \mathrm{m}$ wide and $1.0-1.5 \mu \mathrm{m}$ long. Colonies on $\mathrm{R} 2 \mathrm{~A}$ medium are
Table 2 Distinctive features of $D$. nitraria $36-5-1^{\mathrm{T}}$ and the closely related species, D. pacifica and D. geojensis

\begin{tabular}{|c|c|c|c|}
\hline Characteristic & 1 & 2 & 3 \\
\hline Nitrate reductase & + & - & + \\
\hline \multicolumn{4}{|l|}{ Hydrolysis of } \\
\hline Casein & + & + & - \\
\hline Aesculin & + & + & + \\
\hline Salicine & + & + & + \\
\hline Urea & + & + & + \\
\hline Casei & - & - & - \\
\hline Tween 80 & - & - & - \\
\hline Gelatin & + & - & + \\
\hline Starch & - & - & - \\
\hline L-Tyrosine & - & + & + \\
\hline Inuline & + & & - \\
\hline$N$-acetyl glucosamine & + & + & + \\
\hline Phenylacetic acid & - & - & - \\
\hline \multicolumn{4}{|l|}{ Assimilation of } \\
\hline Fructose & + & + & + \\
\hline Gentiobiose & + & + & + \\
\hline Sucrose & - & + & + \\
\hline Asparagine & - & + & + \\
\hline Arginine & + & - & + \\
\hline Erythritol & - & - & - \\
\hline Sodium glutamate & - & + & + \\
\hline Sodium malate & - & + & + \\
\hline Sodium citrate & - & - & + \\
\hline Pyruvic acid sodium & + & + & + \\
\hline Rhamnose & - & + & - \\
\hline Ribose & - & + & + \\
\hline D-Arabinose & + & - & - \\
\hline L-Arabinose & + & + & + \\
\hline Salicin & - & + & + \\
\hline Raffinose & - & + & + \\
\hline D-Trehalose & + & + & + \\
\hline Succinic acid & + & + & + \\
\hline D-Galactose & - & - & - \\
\hline D-Adonitol & + & - & - \\
\hline Xylitol & - & - & - \\
\hline Mannopyranose & - & - & - \\
\hline L-Homocysteine & + & + & + \\
\hline L-Alanine & + & + & + \\
\hline DL-Histidine & + & + & + \\
\hline L-Glutamic & + & + & + \\
\hline Methionine & + & + & + \\
\hline L-Phenylalanine & + & + & + \\
\hline L-Threonine & + & + & + \\
\hline
\end{tabular}


Table 2 continued

\begin{tabular}{|c|c|c|c|}
\hline Characteristic & 1 & 2 & 3 \\
\hline L-Leucine & - & + & + \\
\hline Xanthine & + & + & + \\
\hline Tryptophan & - & - & - \\
\hline D-Melezitose & + & - & - \\
\hline Potassium gluconate & - & - & - \\
\hline Potassium 2-ketogluconate & - & - & - \\
\hline Potassium 5-ketogluconate & - & - & - \\
\hline \multicolumn{4}{|l|}{ Acid production from } \\
\hline D-Xylose & + & + & + \\
\hline D-Cellobiose & + & + & + \\
\hline L-Xylose & + & - & - \\
\hline D-Glucose & + & + & + \\
\hline L-Fucose & + & - & - \\
\hline D-Fucose & - & - & - \\
\hline D-Sorbitol & + & + & + \\
\hline Sorbose & + & - & + \\
\hline Inositol & - & + & + \\
\hline Mannitol & - & + & + \\
\hline Methyl a-D-mannose & + & + & + \\
\hline$N$-acetyl glucosamine & + & + & + \\
\hline Amygdalin & + & - & - \\
\hline Maltose & + & + & + \\
\hline Lactose & - & + & - \\
\hline D-Tagatose & + & - & + \\
\hline Sucrose & + & + & + \\
\hline D-Melibiose & - & + & + \\
\hline \multicolumn{4}{|l|}{ Resistance to antibiotics } \\
\hline Polymyxin & - & + & + \\
\hline Streptomycin & - & + & - \\
\hline Gentamicin & - & + & - \\
\hline Neomycin & + & + & + \\
\hline Tetracycline & + & - & - \\
\hline Chloramphenicol & - & + & - \\
\hline Ampicillin & + & - & - \\
\hline Kanamycin & - & + & - \\
\hline \multicolumn{4}{|l|}{ Production of } \\
\hline Oxidase & + & + & + \\
\hline Cytochrome oxidase & + & + & + \\
\hline Catalase & + & + & + \\
\hline
\end{tabular}

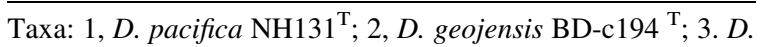
nitraria $36-5-1^{\mathrm{T}}$. + , positive; - , negative

circular, convex, white and semitranslucent, with a typical diameter of 3-5 $\mathrm{mm}$ after 3 days of growth at $25{ }^{\circ} \mathrm{C}$. Cells are positive for utilization of inositol, L-

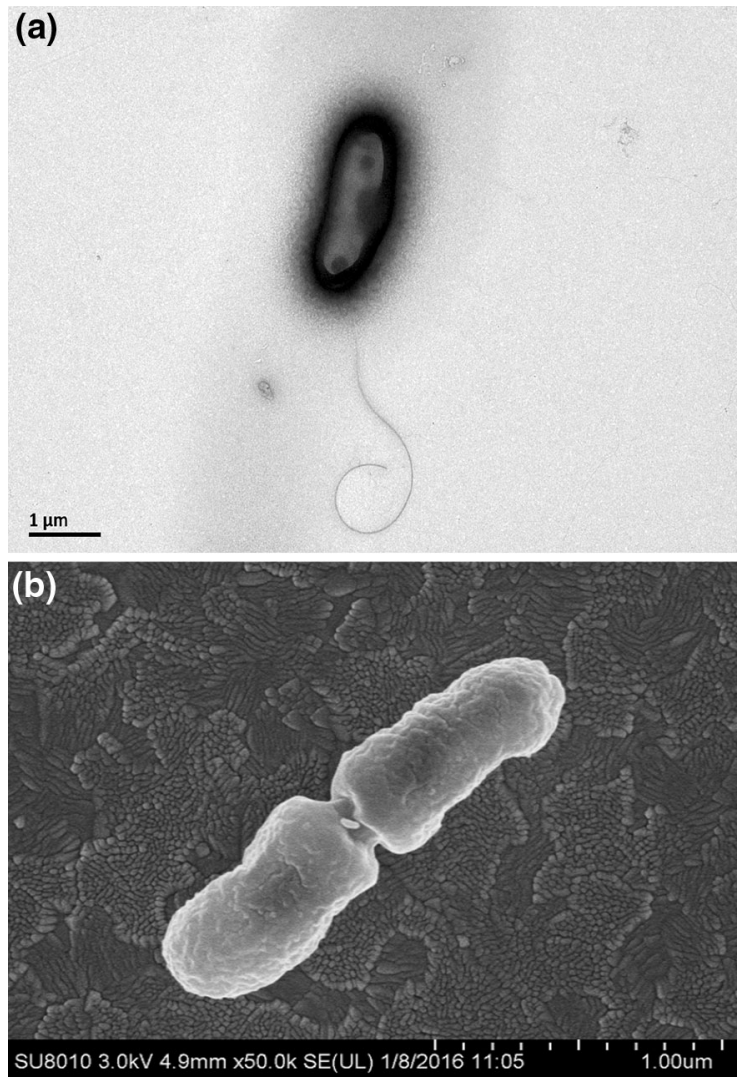

Fig. 3 a Scanning electron micrograph of strain $36-5-1^{\mathrm{T}}$ grown on YMA media for $48 \mathrm{~h}$. Bar indicates $1.0 \mu \mathrm{m}$. b Transmission electron micrograph of strain $36-5-1^{\mathrm{T}}$ grown on YMA media for 48 h. Bar indicates $1.0 \mu \mathrm{m}$

arabinose, D-mannitol, D-sorbitol, gentiobiose, glucose, sodium citrate, sodium malonate, pyruvic acid sodium, sucrose, D-xylose, D-ribose, D-fructose, Dmannose, D-maltose, sodium acetate, esculine, salicine, amygdaline, D-melibiose, D-saccharose, D-trehalose, D-raffinose, and D-tyranose as sole carbon sources but negative for D-galactose, L-rhamnose, erythritol, D-arabinose, D-adonitol, L-xylose, L-sorbose, inuline, dulcitol, xylitol, L-fucose, D-fucose, Darabitol, D-lactose and mannopyranose as the sole carbon sources. Cells are positive for utilization of $\mathrm{L}-$ homocysteine, L-alanine, DL-histidine, L-tyrosine, Lleucine, L-threonine, methionine, L-phenylalanine, Larginine, L-glutamic, aspartic acid and xanthine but negative for tryptophan as a sole nitrogen source. Optimum growth occurs at $30{ }^{\circ} \mathrm{C}$ and the strain's growth is inhibited at temperature extremes of 4 and $40{ }^{\circ} \mathrm{C}$ in R2A medium, as well as at 37 and $40{ }^{\circ} \mathrm{C}$ 
Table 3 Cellular fatty acids of strain $36-5-1^{\mathrm{T}}$

\begin{tabular}{ll}
\hline Fatty acid & D. nitraria $36-5-1^{\mathrm{T}}$ \\
\hline $\mathrm{C}_{14: 0}$ & 1.6 \\
$\mathrm{C}_{15: 0}$ & - \\
$\mathrm{C}_{16: 0}$ & 36.8 \\
$\mathrm{C}_{17: 0}$ & 0.6 \\
$\mathrm{C}_{18: 0}$ & 7.3 \\
$\mathrm{C}_{19: 0}$ & - \\
$\mathrm{C}_{16: 0} \mathrm{~N}$ alcohol & 14.6 \\
$\mathrm{C}_{17: 0}$ cyclo & 0.7 \\
$\mathrm{C}_{16: 1} \omega 7 c 1_{16: 1} \omega 6 c$ & 1.9 \\
$\mathrm{C}_{17: 1} \omega 8 c$ & - \\
$\mathrm{C}_{17: 1} \omega 6 c$ & - \\
$\mathrm{C}_{18: 1} \omega 5 c$ & - \\
$\mathrm{C}_{18: 1} \omega 7 c$ & 9.4 \\
$\mathrm{C}_{18: 1} \omega 9 c$ & - \\
$\mathrm{C}_{20: 1} \omega 7 c$ & - \\
$\mathrm{C}_{18: 3} \omega 6 c(6,9,12)$ & 1.3 \\
$\mathrm{C}_{8: 0} 3-\mathrm{OH}$ & - \\
$\mathrm{C}_{18: 0} 3-\mathrm{OH}$ & 2.5 \\
$10-\mathrm{Methyl} \mathrm{C}_{17: 0}$ & 12.6 \\
$11-\mathrm{Methyl} \mathrm{C}_{18: 1} \omega 7 \mathrm{c}$ & 4.7 \\
$\mathrm{C}_{19: 0}$ cyclo $\omega 8 c$ & 5.5 \\
ECL18.814 & - \\
\hline
\end{tabular}

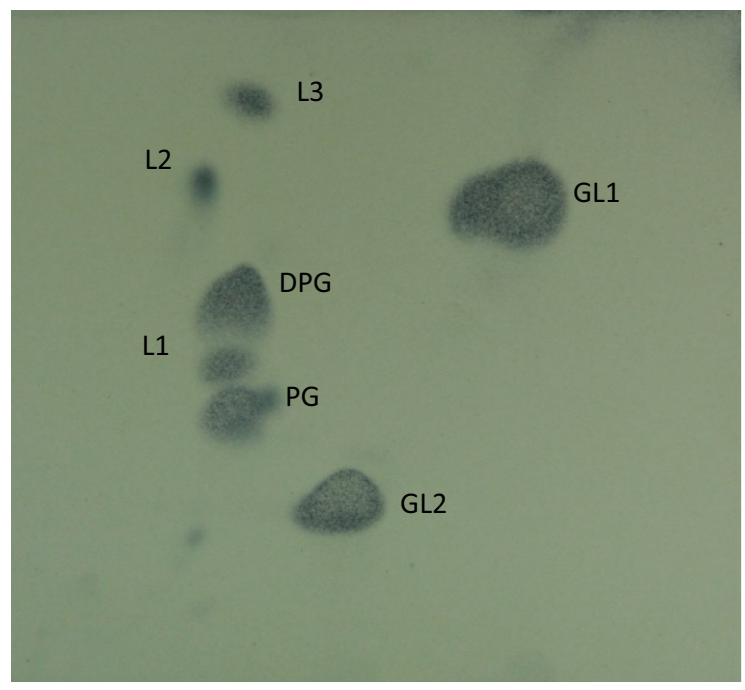

Fig. 4 Polar lipid profile of strain $36-5-1^{\mathrm{T}}$ after two-dimensional TLC and staining with molybdatophosphoric acid. DPG diphosphatidylglycerol, $P G$ phosphatidylglycerol, $G L$ unidentified glycolipid L, 1-3 unidentified polar lipids when grown in LB and YMA media, respectively. Optimum $\mathrm{pH}$ for growth is at 7.0 while some growth is observed up to $\mathrm{pH}$ levels of 11.0. Cells grow on YMA in the presence of $7 \%(\mathrm{w} / \mathrm{v}) \mathrm{NaCl}$ but do not grow in media supplemented with $0.1 \%$ malachite green, $0.1 \%$ methylene blue and $0.1 \%$ neutral red. Cells are sensitive to $10 \mu \mathrm{g} \mathrm{ml}^{-1}$ tetracycline, gentamicin, chloramphenicol, ampicillin, streptomycin and kanamycin, but resistant to polymyxin and neomycin. Cells are negative for casein hydrolysis, litmus milk alkali production, nitrate reduction, Voges-Proskauer, Dmelezitose, potassium gluconate, potassium 2-ketogluconate and potassium 5-ketogluconate, but positive for D-cellobiose, urease, cytochrome oxidase, catalase oxidase and hydrolysis of gelatin. Cells can assimilate $\mathrm{N}$-acetyl glucosamine but not phenylacetic acid. The predominant ubiquinone is $\mathrm{Q}-10$. The main cellular fatty acid is $\mathrm{C}_{16: 0}$.

The type strain, $36-5-1^{\mathrm{T}} \quad\left(=\mathrm{CGMCC} 1.15704^{\mathrm{T}}=-\right.$ NBRC112416 ${ }^{\mathrm{T}}$ ), was isolated from the nodules of Nitraria sibirica grown in Hexi corridor in Zhangye city, Gansu province of China.

Acknowledgements This work was supported by projects from National Science Foundation of China (31360004), China Scholarship Council fund and Education Department of Gansu Province (2014A-107). We would like to express our gratitude to Professor Chengying Jiang, Baojun Wang and Hongcan Liu (Institute of Microbiology, Chinese Academy of Sciences, Beijing, China) for providing the reference type strains and depositing the type strain.

Conflict of interest The authors declare no conflict of interest.

Open Access This article is distributed under the terms of the Creative Commons Attribution 4.0 International License (http:// creativecommons.org/licenses/by/4.0/), which permits unrestricted use, distribution, and reproduction in any medium, provided you give appropriate credit to the original author(s) and the source, provide a link to the Creative Commons license, and indicate if changes were made.

\section{References}

Altschul SF, Gish W, Miller W, Myers EW, Lipman DJ (1990) Basic local alignment search tool. J Mol Biol 215:403-410

Bautista VV, Monsalud RG, Yokota A (2010) Devosia yakushimensis sp. nov., isolated from root nodules of Pueraria lobata (Willd.) Ohwi. Int J Syst Evol Microbiol 60:627-632 
Bertani G (1951) STUDIES ON LYSOGENESIS I.: The Mode of Phage Liberation by Lysogenic Escherichia coli. J Bacteriol 62:293

De Ley J, Cattoir H, Reynaerts A (1970) The quantitative measurement of DNA hybridization from renaturation rates. Eur J Biochem 12:133-142

Elliott GN, Chen WM, Bontemps C, Chou JH, Young JPW, Sprent JI, James EK (2007) Nodulation of Cyclopia spp. (Leguminosae, Papilionoideae) by Burkholderia tuberum. Ann Bot (Lond) 100:1403-1411

Felsenstein J (1985) Confidence limits on phylogenies: an approach using the bootstrap. Evolution 39:783-791

Foster JW (1944) Microbiological aspects of riboflavin. I. Introduction. II. Bacterial oxidation of riboflavin to lumochrome. J Bacteriol 47:27-41

Galtier N, Gouy M, Gautier C (1996) SEAVIEW and PHYLO_WIN: two graphic tools for sequence alignment and molecular phylogeny. Comput Appl Biosci 12:543-548

Gao JL, Sun JG, Li Y, Wang ET, Chen WX (1994) Numerical taxonomy and DNA relatedness of tropical rhizobia isolated from Hainan Province, China. Int J Syst Bacteriol 44:151-158

Gaunt MW, Turner SL, Rigottier-Gois L, Lloyd-Macgilp SA, Young JPW (2001) Phylogenies of atpD and recA support the small subunit rRNA-based classification of rhizobia. Int J Syst Evol Microbiol 51:2037-2048

Graham PH, Sadowsky MJ, Keyser HH, Barnet YM, Bradley RS, Cooper JE, De Ley DJ, Jarvis BDW, Roslycky EB (1991) Proposed minimal standards for the description of new genera and species of root- and stem-nodulating bacteria. Int J Syst Bacteriol 41:582-587

Jia YY, Sun C, Pan J, Zhang WY, Zhang XQ, Huo YY, Zhu XF, Wu M (2014) Devosia pacifica sp. nov., isolated from deep-sea sediment. Int J Syst Bacteriol 64:2637-2641

Kates M (1986) Techniques of lipidology. Sole distributors for the USA and Canada, Elsevier, New York

Laguerre G, Nour SM, Macheret V, Sanjuan J, Drouin P, Amarger N (2001) Classification of rhizobia based on nodC and nifH gene analysis reveals a close phylogenetic relationship among Phaseolus vulgaris symbionts. Microbiology 147:981-993

Liu YM (1999) Pharmacography of Uighur, part II. Science/ Technology and Health Publishing House of Xinjiang, Urumqi

Marmur J, Doty P (1962) Determination of the base composition of 171 deoxyribonucleic acid from its thermal denaturation temperature. J Mol Biol 5:109-118

Nakagawa Y, Sakane T, Yokota A (1996) Transfer of "Pseudomonas riboflavina" (Foster 1944), a gram-negative, motile rod with long-chain 3-hydroxy fatty acids, to Devosia riboflavinagen. nov., sp. nov., nom. rev. Int J Syst Bacteriol 46:16-22

Reasoner DJ, Geldreich EE (1985) A new medium for the enumeration and subculture of bacteria from potable water. Appl Environ Microbiol 49:1-7

Rivas R, Willems A, Subba-rao NS, Mateos PF, Dazzo FB, Kroppenstedt RM, Martinez-molina E, Gills M, Velazquez E (2003) Description of Devosia neptuniae sp. nov. that nodulates and fixes nitrogen in symbiosis with Neptunia natans, an aquatic legume from India. Syst Appl Microbiol 26:47-53

Ryu SH, Chung BS, Le NT, Jang HH, Yun PY, Park W, Jeon CO (2008) Devosia geojensis sp. nov., isolated from dieselcontaminated soil in Korea. Int J Syst Evol Microbiol 58:633-636

Saitou N, Nei M (1987) The neighbor-joining method: a new method for reconstructing phylogenetic trees. Mol Biol Evol 4:406-425

Salem JH, Chevalot I, Harscoat-Schiavo C, Paris C, Fick M, Humeau C (2011) Biological activities of flavonoids from Nitraria retusa (Forssk.) Asch. and their acylated derivatives. Food Chem 124:486-494

Sasser M (1990) Identification of bacteria by gas chromatography of cellular fatty acids. MIDI Technical Note 101. MIDI Inc., Newark

Suo Y, Wang L (2010) Extraction of Nitraria tangutorum seed lipid using different extraction methods and analysis of its fatty acids by HPLC fluorescence detection and on-line MS identification. Eur J Lipid Sci Technol 112:390-399

Terefework Z, Kaijalainen S, Lindström K (2001) AFLP fingerprinting as a tool to study the genetic diversity of Rhizobium galegae. J Biotechnol 91:169-180

Thompson JD, Higgins DG, Gibson TJ (1994) CLUSTAL_W: improving the sensitivity of progressive multiple sequence alignment through sequence weighting, position-specific gap penalties and weight matrix choice. Nucleic Acids Res 22:4673-4680

Tighe SW, de Lajudie P, Dipietro K, Lindström K, Nick G, Jarvis BD (2000) Analysis of cellular fatty acids and phenotypic relationships of Agrobacterium, Bradyrhizobium, Mesorhizobium, Rhizobium and Ensifer species using the Sherlock Microbial Identification System. Int J Syst Evol Microbiol 50:787-801

Tulyaganov TS, Allaberdiev FK (2001) Alkaloids of Nitraria sibirica. Dihydroschoberine and nitrabirine N-oxide. Chem Nat Compd 37:556-558

Tulyaganov TS, Allaberdiev FK (2003) Alkaloids from plants of the Nitraria genus. Structure of sibiridine. Chem Nat Compd 39:292-293

Turner SL, Young JPW (2000) The glutamine synthetases of rhizobia: phylogenetics and evolutionary implications. Mol Biol Evol 17:309-319

Vincent JM (1970) A manual for the practical study of root nodule bacteria. Blackwell, Oxford

Xu L, Zhang Y, Deng ZS, Zhao L, Wei XL, Wei GH (2013) Rhizobium qilianshanense sp. nov., a novel species isolated from root nodule of Oxytropis ochrocephala Bunge in China. Antonie van Leeuwenhoek 103:559-565

Xu L, Shi JF, Li CX, Zhu SA, Li B (2016) Rhizobium hedysari sp. nov., a novel species isolated from a root nodule of Hedysarum multijugum in China. Antonie Van Leeuwenhoek. doi:10.1007/s10482-016-0817-z

Yoon SH, Ha SM, Kwon S, Lim J, Kim Y, Seo H, Chun J (2016) Introducing EzBioCloud: a taxonomically united database of 16S rRNA and whole genome assemblies. Int J Syst Evol Microbiol. doi:10.1099/ijsem.0.001755

Zhao KF, Fan H (2002) Ungar Survey of halophyte species in China. Plant Sci 163:491-498 